\title{
Pengembangan Aplikasi Android Untuk Studi Bahasa Carakan Madura
}

\author{
Moh. Rochman Wahid Maulana \\ Moh. Rochman Wahid Maulana (Program Studi S2 Pendidikan Teknologi dan Kejuruan, Universitas Negeri Surabaya) \\ mwmnanang162@gmail.com
}

\begin{abstract}
Abstrak- Perangkat mobile menjadi sangat populer saat ini. Buku teks bahasa dengan alat bantu pembelajaran pada perangkat mobile dapat sangat membantu siswa dengan studi mereka. Penulis telah mengembangkan alat bantu pembelajaran pada perangkat mobile yang dapat digunakan dalam program bahasa. Makalah ini memperkenalkan sebuah aplikasi android yang dapat membantu siswa untuk menghafal kosakata. Kosakata didasarkan pada buku teks yang diterbitkan. Siswa yang menggunakan buku teks dalam program mereka dapat meninjau kosakata buku teks menggunakan flashcards virtual dan beberapa kuis pilihan yang disediakan oleh aplikasi yang berjalan pada perangkat Android.
\end{abstract}

Kata Kunci- Android; studi bahasa; alat bantu pembelajaran; aplikasi mobile; Pengembangan perangkat lunak.

\section{PENDAHUluan}

Pembelajaran disekolah saat ini banyak yang memanfaatkan media pembelajaran dan alat bantu belajar misalkan menggunakan media presentasi, dll. Alat bantu belajar adalah alat penting untuk pembelajar karena mereka membantu siswa untuk mengembangkan keterampilan belajarnya. Dalam Carakan Madura saja yang ditawarkan oleh penulis, pengajar melakukan berbagai kegiatan belajar dan menggunakan alat yang berbeda. Misalnya, siswa diberi puzzles silang di mana mereka dapat membaca petunjuk dan kemudian mengisi kekosongan dengan kosa kata yang sesuai yang telah diajarkan. Dalam kegiatan lain, siswa diminta untuk mengidentifikasi kata-kata yang hilang dalam dialog. alat dan kegiatan ini adalah cara interaktif dan menyenangkan yang membantu siswa untuk menghafal kata-kata baru secara efektif.

Berdasarkan hal tersebut, maka penulis tertarik untuk membuat alat bantu belajar di sekolah. Dengan adanya aplikasi ini diharapkan dapat mempermudah dan membantu guru bahasa madura di sekolah dalam penyajian pembelajaran dan quiz akan terkemas secara praktis dan hasil jawaban quiz akan dinilai secara otomatis.

Pada rancang aplikasi quiz carakan madura, kami menggunakan sistem operasi Android dan database SQLite yang mengacu pada Aplikasi berbasis android.

Rancang Bangun aplikasi quiz carakan madura, dimana aplikasi ini dapat diakses oleh semua handhone android minimal gingerbread, sehingga siswa dapat mengakses quiz ini dengan model soal multiple choice yang random dan tempat. Dari hasil aplikasi tersebut maka berguna untuk pembelajaran di sekolah maupun di luar sekolah.

\section{A. Tujuan Penelitian}

Dengan adanya aplikasi ini diharapkan dapat mempermudah dan membantu guru bahasa madura di sekolah dalam penyajian pembelajaran, quiz akan terkemas secara praktis dan hasil jawaban quiz akan dinilai secara otomatis.

\section{B. Manfaat Manfaat Penelitian}

Aplikasi pembelajaran bahasa madura diharapkan siswa dengan mudah mempelajari bahasa madura dengan teknologi Android.

\section{TINJAUAN PUSTAKA}

\section{A. Pemrograman Java}

Java adalah bahasa pemrograman yang dapat dijalankan di berbagai komputer termasuk telepon genggam. Bahasa ini awalnya dibuat oleh James Gosling saat masih bergabung di Sun Microsystems saat ini merupakan bagian dari Oracle dan dirilis tahun1995. Bahasa ini banyak mengadopsi sintaksis yang terdapat pada $\mathrm{C}$ dan $\mathrm{C}++$ namun dengan sintaksis model objek yang lebih sederhana serta dukungan rutin-rutin aras bawah yang minimal. Aplikasi-aplikasi berbasis java umumnya dikompilasi ke dalam p-code (bytecode) dan dapat dijalankan pada berbagai Mesin Virtual Java (JVM). Java merupakan bahasa pemrograman yang bersifat umum/nonspesifik (general purpose), dan secara khusus didisain untuk memanfaatkan dependensi implementasi seminimal mungkin. Karena fungsionalitasnya yang memungkinkan aplikasi java mampu berjalan di beberapa platform sistem operasi yang berbeda, java dikenal pula dengan slogannya, "Tulis sekali, jalankan di mana pun". Saat ini java merupakan bahasa pemrograman yang paling populer digunakan, dan secara luas dimanfaatkan dalam pengembangan berbagai jenis perangkat lunak aplikasi ataupun aplikasi.

\section{B. Sejarah Perkembangan}

Bahasa pemrograman Java terlahir dari The Green Project, yang berjalan selama 18 bulan, dari awal tahun 1991 hingga musim panas 1992. Proyek tersebut belum menggunakan versi yang dinamakan Oak. Proyek ini dimotori oleh Patrick Naughton, Mike Sheridan, dan James Gosling, beserta sembilan pemrogram lainnya dari Sun Microsystems. Salah 
satu hasil proyek ini adalah maskot Duke yang dibuat oleh Joe Palrang.

Pertemuan proyek berlangsung di sebuah gedung perkantoran Sand Hill Road di Menlo Park. Sekitar musim panas 1992 proyek ini ditutup dengan menghasilkan sebuah program Java Oak pertama, yang ditujukan sebagai pengendali sebuah peralatan dengan teknologi layar sentuh (touch screen), seperti pada PDA sekarang ini. Teknologi baru ini dinamai "*7" (Star Seven).

Setelah era Star Seven selesai, sebuah anak perusahaan Tv kabel tertarik ditambah beberapa orang dari proyek The Green Project. Mereka memusatkan kegiatannya pada sebuah ruangan kantor di 100 Hamilton Avenue, Palo Alto.

Perusahaan baru ini bertambah maju: jumlah karyawan meningkat dalam waktu singkat dari 13 menjadi 70 orang. Pada rentang waktu ini juga ditetapkan pemakaian Internetsebagai medium yang menjembatani kerja dan ide di antara mereka. Pada awal tahun 1990-an, Internet masih merupakan rintisan, yang dipakai hanya di kalangan akademisidan militer.

Mereka menjadikan perambah (browser) Mosaic sebagai landasan awal untuk membuat perambah Java pertama yang dinamai Web Runner, terinsipirasi dari film 1980-an, Blade Runner. Pada perkembangan rilis pertama, Web Runner berganti nama menjadi Hot Java.

Pada sekitar bulan Maret 1995, untuk pertama kali kode sumber Java versi 1.0a2 dibuka. Kesuksesan mereka diikuti dengan untuk pemberitaan pertama kali pada surat kabarSan Jose Mercury News pada tanggal 23 Mei 1995.

Sayang terjadi perpecahan di antara mereka suatu hari pada pukul 04.00 di sebuah ruangan hotel Sheraton Palace. Tiga dari pimpinan utama proyek, Eric Schmidt dan George Paolini dari Sun Microsystems bersama Marc Andreessen, membentuk Netscape.

Nama Oak, diambil dari pohon oak yang tumbuh di depan jendela ruangan kerja "Bapak Java", James Gosling. Nama Oak ini tidak dipakai untuk versi release Java karena sebuah perangkat lunak lain sudah terdaftar dengan merek dagang tersebut, sehingga diambil nama penggantinya menjadi "Java". Nama ini diambil dari kopi murni yang digiling langsung dari biji (kopi tubruk) kesukaan Gosling. Konon kopi ini berasal dari Pulau Jawa. Jadi nama bahasa pemrograman Java tidak lain berasal dari kata Jawa (bahasa Inggris untuk Jawa adalah Java).

\section{Kelebihan}

1) Multiplatform. Kelebihan utama dari Java ialah dapat dijalankan di beberapa platform / sistem operasi komputer, sesuai dengan prinsip tulis sekali, jalankan di mana saja. Dengan kelebihan ini pemrogram cukup menulis sebuah program Java dan dikompilasi (diubah, dari bahasa yang dimengerti manusia menjadi bahasa mesin / bytecode) sekali lalu hasilnya dapat dijalankan di atas beberapa platform tanpa perubahan. Kelebihan ini memungkinkan sebuah program berbasis java dikerjakan di atas operating system Linux tetapi dijalankan dengan baik di atas Microsoft Windows. Platform yang didukung sampai saat ini adalah Microsoft Windows, Linux, Mac OS dan Sun Solaris. Penyebabnya adalah setiap sistem operasi menggunakan programnya sendiri-sendiri (yang dapat diunduh dari situs Java) untuk meninterpretasikan bytecode tersebut.

2) OOP (Object Oriented Programming - Pemrogram Berorientasi Objek)

3) Perpustakaan Kelas Yang Lengkap, Java terkenal dengan kelengkapan library perpustakaan (kumpulan program program yang disertakan dalam pemrograman java) yang sangat memudahkan dalam penggunaan oleh para pemrogram untuk membangun aplikasinya. Kelengkapan perpustakaan ini ditambah dengan keberadaan komunitas Java yang besar yang terus menerus membuat perpustakaan-perpustakaan baru untuk melingkupi seluruh kebutuhan pembangunan aplikasi.

4) Bergaya $\mathrm{C}++$, memiliki sintaks seperti bahasa pemrograman $\mathrm{C}++$ sehingga menarik banyak pemrogram $\mathrm{C}++$ untuk pindah ke Java. Saat ini pengguna Java sangat banyak, sebagian besar adalah pemrogram $\mathrm{C}++$ yang pindah ke Java. Universitas-universitas di Amerika Serikat juga mulai berpindah dengan mengajarkan Java kepada murid-murid yang baru karena lebih mudah dipahami oleh murid dan dapat berguna juga bagi mereka yang bukan mengambil jurusan komputer.

5) Pengumpulan sampah otomatis, memiliki fasilitas pengaturan penggunaan memori sehingga para pemrogram tidak perlu melakukan pengaturan memori secara langsung (seperti halnya dalam bahasa $\mathrm{C}++$ yang dipakai secara luas).

\section{Kekurangan}

1) Tulis sekali, jalankan di mana saja - Masih ada beberapa hal yang tidak kompatibel antara platform satu dengan platform lain. Untuk J2SE, misalnya SWT-AWT bridgeyang sampai sekarang tidak berfungsi pada Mac OS X.

2) Mudah didekompilasi. Dekompilasi adalah proses membalikkan dari kode jadi menjadi kode sumber. Ini dimungkinkan karena kode jadi Java merupakan bytecode yang menyimpan banyak atribut bahasa tingkat tinggi, seperti nama-nama kelas, metode, dan tipe data. Hal yang sama juga terjadi pada Microsoft .NET Platform. Dengan demikian, algoritma yang digunakan program akan lebih sulit disembunyikan dan mudah dibajak/direverse-engineer.

3) Penggunaan memori yang banyak. Penggunaan memori untuk program berbasis Java jauh lebih besar daripada bahasa tingkat tinggi generasi sebelumnya seperti $\mathrm{C} / \mathrm{C}++$ dan Pascal (lebih spesifik lagi, Delphi dan Object Pascal). Biasanya ini bukan merupakan masalah bagi pihak yang menggunakan teknologi terbaru (karena trend memori terpasang makin murah), tetapi menjadi masalah bagi mereka yang masih harus berkutat dengan mesin komputer berumur lebih dari 4 tahun.

\section{E. Android}

Android (/'æn.droId/; an-droyd) adalah sistem operasi berbasis Linux yang dirancang untuk perangkat bergerak layar sentuh seperti telepon pintar dan komputer tablet. 
Android adalah sistem operasi dengan sumber terbuka, dan Google merilis kodenya di bawah Lisensi Apache.[11] Kode dengan sumber terbuka dan lisensi perizinan pada Android memungkinkan perangkat lunak untuk dimodifikasi secara bebas dan didistribusikan oleh para pembuat perangkat, operator nirkabel, dan pengembang aplikasi. Selain itu, Android memiliki sejumlah besar komunitas pengembang aplikasi (apps) yang memperluas fungsionalitas perangkat, umumnya ditulis dalam versi kustomisasi bahasa pemrograman Java. Pada bulan Oktober 2013, ada lebih dari satu juta aplikasi yang tersedia untuk Android, dan sekitar 50 miliar aplikasi telah diunduh dari Google Play, toko aplikasi utama Android. Sebuah survei pada bulan April-Mei 2013 menemukan bahwa Android adalah platform paling populer bagi para pengembang, digunakan oleh $71 \%$ pengembang aplikasi bergerak. Di Google I/O 2014, Google melaporkan terdapat lebih dari satu miliar pengguna aktif bulanan Android, meningkat dari 583 juta pada bulan Juni 2013.

Pengembangan perangkat lunak Android adalah proses di mana aplikasi baru diciptakan untuk sistem operasi Android. Aplikasi tersebut biasanya dikembangkan dalam bahasa pemrograman Java dengan menggunakan Software Development Kit (SDK) Android, tetapi perkakas lainnya juga tersedia. Pada Juli 2013, lebih dari satu juta aplikasi telah dikembangkan untuk Android, dengan lebih 25 juta unduhan. Sebuah riset menunjukkan bahwa lebih $67 \%$ pengembang aplikasi seluler menggunakan platformAndroid. Pada Q2 2012, sekitar 105 juta unit telepon cerdas Android telah dipasarkan, dengan total pangsa pasar $68 \%$ secara keseluruhan.

\section{F. Sejarah Andoid}

Android, Inc. didirikan di Palo Alto, California, pada bulan Oktober 2003 oleh Andy Rubin (pendiri Danger), Rich Miner (pendiri Wildfire Communications, Inc.), Nick Sears (mantan VP T-Mobile), dan Chris White (kepala desain dan pengembangan antarmuka WebTV) untuk mengembangkan "perangkat seluler pintar yang lebih sadar akan lokasi dan preferensi penggunanya".

Tujuan awal pengembangan Android adalah untuk mengembangkan sebuah sistem operasi canggih yang diperuntukkan bagi kamera digital, namun kemudian disadari bahwa pasar untuk perangkat tersebut tidak cukup besar, dan pengembangan Android lalu dialihkan bagi pasar telepon pintar untuk menyaingi Symbian dan Windows Mobile (iPhone Apple belum dirilis pada saat itu).

Meskipun para pengembang Android adalah pakar-pakar teknologi yang berpengalaman, Android Inc. dioperasikan secara diam-diam, hanya diungkapkan bahwa para pengembang sedang menciptakan sebuah perangkat lunak yang diperuntukkan bagi telepon seluler.

Google mengakuisisi Android Inc. pada tanggal 17 Agustus 2005, menjadikannya sebagai anak perusahaan yang sepenuhnya dimiliki oleh Google. Pendiri Android Inc. seperti Rubin, Miner dan White tetap bekerja di perusahaan setelah diakuisisi oleh Google. Setelah itu, tidak banyak yang diketahui tentang perkembangan Android Inc., namun banyak anggapan yang menyatakan bahwa Google berencana untuk memasuki pasar telepon seluler dengan tindakannya ini.

Di Google, tim yang dipimpin oleh Rubin mulai mengembangkan platform perangkat seluler dengan menggunakan kernel Linux. Google memasarkan platform tersebut kepada produsen perangkat seluler danoperator nirkabel, dengan janji bahwa mereka menyediakan sistem yang fleksibel dan bisa diperbarui. Google telah memilih beberapa mitra perusahaan perangkat lunak dan perangkat keras, serta mengisyaratkan kepada operator seluler bahwa kerja sama ini terbuka bagi siapapun yang ingin berpartisipasi.

Pada tanggal 5 November 2007, Open Handset Alliance (OHA) didirikan. OHA adalah konsorsium dari perusahaanperusahaan teknologi seperti Google, produsen perangkat seluler seperti HTC, Sony dan Samsung, operator nirkabel seperti Sprint Nextel dan T-Mobile, serta produsen chipset seperti Qualcomm dan Texas Instruments. OHA sendiri bertujuan untuk mengembangkan standar terbuka bagi perangkat seluler. Saat itu, Android diresmikan sebagai produk pertamanya; sebuah platform perangkat seluler yang menggunakan kernel Linux versi 2.6. Telepon seluler komersial pertama yang menggunakan sistem operasi Android adalah HTC Dream, yang diluncurkan pada 22 Oktober 2008.

\section{G. Aplikasi Android}

Aplikasi Android dikembangkan dalam bahasa pemrograman Java dengan menggunakan kit pengembangan perangkat lunak Android (SDK). SDK ini terdiri dari seperangkat perkakas pengembangan, termasuk debugger, perpustakaan perangkat lunak, emulator handset yang berbasis QEMU, dokumentasi, kode sampel, dan tutorial. Didukung secara resmi oleh lingkungan pengembangan terpadu (IDE) Eclipse, yang menggunakan plugin Android Development Tools (ADT). Perkakas pengembangan lain yang tersedia di antaranya adalah Native Development Kit untuk aplikasi atau ekstensi dalam $\mathrm{C}$ atau $\mathrm{C}++$, Google App Inventor, lingkungan visual untuk pemrogram pemula, dan berbagai kerangka kerja aplikasi web seluler lintas platform.

\section{H. Perkembangan Versi OS Android}

1) Android Cupcake version 1.5

2) Android Donut version 1.6.

3) Android Eclair version 2.0.

4) Android Froyo version 2.2.

5) Android Gingerbread version 2.3 .

6) Android Honeycomb version 3.0.

7) Android Ice Cream Sandwich version 4.0.

8) Android Jellybean version 4.1

9) Android Kitkat version 4.4

10) Android Lolipop version 5.0

11) Android marshmallow version 6.0 


\section{Arsitektur Android}

Android dibangun dengan menggunakan asas object oriented, dimana elemen-elemen penyusun sistem operasinya berupa objek yang dapat kita gunakan kembali/reusable. Agar bisa membuat aplikasi dengan baik, tentunya kita harus mengetahui arsitektur OS Android beserta elemen elemennya. Gambar dibawah merupakan skema pembagian elemen pada arsitektur Android. Secara garis besar arsitektur android terdiri dari empat layer komponen, yaitu:

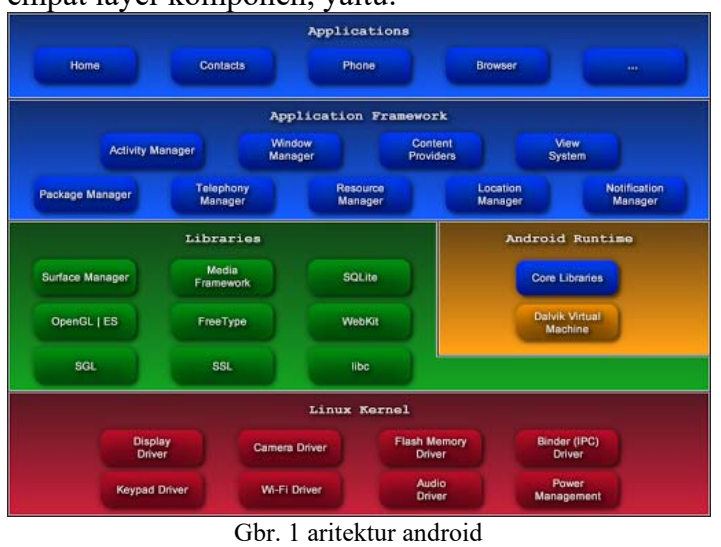

1) Layer Applications dan Widget Inilah layer pertama pada OS Android, biasa dinamakan layer Applications dan Widget. Layer ini merupakan layer yang berhubungan dengan aplikasi-aplikasi inti yang berjalan pada Android OS.Seperti klien email, program SMS, kalender, browser, peta, kontak, dan lain-lain. Semua aplikasi ini dibuat dengan menggunakan bahasa Java. Apabila kalian membuat aplikasi, maka aplikasi itu ada di layer ini.

2) Layer Applications Framework merupakan layer dimana para pembuat aplikasi menggunakan komponenkomponen yang ada di sini untuk membuat aplikasi mereka. Beberapa contoh komponen yang termasuk di dalam Applications Framework adalah sebagai berikut:

- Views

- Content Provider

- Resource Manager

- Notification Manager

- Activity Manager

3) Layer Libraries merupakan layer tempat fitur-fitur android berada. Pada umumnya libraries diakses untuk menjalankan aplikasi. Beberapa library yang terdapat pada android diantaranya adalah libraries Media untuk memutar media video atau audio, libraries untuk menjalankan tampilan,libraries Graphic, libraries SQLite untuk dukungan database, dan masih banyak library lainnya.

4) Android RunTime merupakan layer yang membuat aplikasi android bisa dijalankan. Android RunTime dibagi menjadi dua bagian yaitu:

- Core Libraries : berfungsi untuk menerjemahkan bahasa Java/C
- Dalvik Virtual Machine : sebuah mesin virtual berbasis register yang dioptimalkan untuk menjalankan fungsifungsi pada Android secara efisien.

5) Linux Kernel merupakan layer tempat keberadaan inti dari operating system android. Layer ini berisi file-file system yang mengatur system processing, memory, resource, drivers, dan sistem android lainnya. Inilah yang membuat file sistem pada Android mirip dengan file sistem pada sistem operasi berbasis Linux. Kernel yang digunakan adalah kernel Linux versi 2.6, dan versi 3.x pada Android versi 4.0 ke atas. Kernel ini berbasis monolithic.

Itulah sdikit gambaran tentang Android arsitektur. Lantas apa yang dimaksud dengan reusabledi sini? Reusable berarti komponen-komponen yang ada pada aplikasi Android bisa kita pakai ketika kita membutuhkannya. Khususnya komponen-komponen pada layer pertama dan kedua. Misalnya kita ingin membuat sebuah web browser sederhana, maka kita hanya perlu menginstanstiasi kelas WebKit browser yang berfungsi untuk menampilkan web page.

\section{J. Database SQLite}

SQLite merupakan sebuah sistem manajemen basisdata relasional yang bersifat ACID-compliant dan memiliki ukuran pustaka kode yang relatif kecil, ditulis dalam bahasa $\mathrm{C}$. SQLite merupakan proyek yang bersifat public domain yang dikerjakan oleh D. Richard Hipp.

Tidak seperti pada paradigma client-server umumnya, Inti SQLite bukanlah sebuah sistem yang mandiri yang berkomunikasi dengan sebuah program, melainkan sebagai bagian integral dari sebuah program secara keseluruhan. Sehingga protokol komunikasi utama yang digunakan adalah melalui pemanggilan API secara langsung melalui bahasa pemrograman. Mekanisme seperti ini tentunya membawa keuntungan karena dapat mereduksi overhead, latency times, dan secara keseluruhan lebih sederhana. Seluruh elemen basisdata (definisi data, tabel, indeks, dan data) disimpan sebagai sebuah file. Kesederhanaan dari sisi disain tersebut bisa diraih dengan cara mengunci keseluruhan file basis data pada saat sebuah transaksi dimulai.

\section{K. Flowchart}

Flowchart atau diagram alir merupakan sebuah diagram dengan simbol-simbol grafis yang menyatakan aliran algoritma atau prosesyang menampilkan langkah-langkah yang disimbolkan dalam bentuk kotak, beserta urutannya dengan menghubungkan masing masing langkah tersebut menggunakan tanda panah. Diagram ini bisa memberi solusi selangkah demi selangkah untuk penyelesaian masalah yang ada di dalam proses atau algoritma tersebut.

TABEL I

SIMBOL - SimBOL FLOWCHART

\begin{tabular}{|c|c|}
\hline Simbol & Penjelasan Simbol \\
\hline & $\begin{array}{l}\text { Simbol arus / flow, yaitu } \\
\text { menyatakan jalannya arus }\end{array}$ \\
\hline
\end{tabular}




\section{suatu proses}
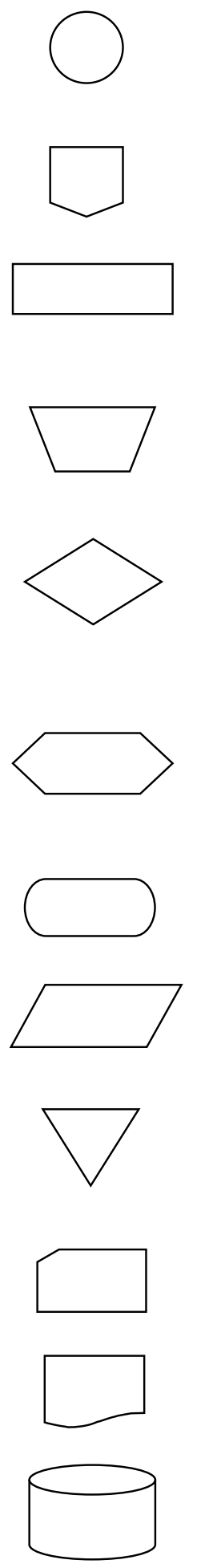

Simbol connector, berfungsi menyatakan sambungan dari proses ke proses lainnya dalam halaman yang sama Simbol offline connector, menyatakan sambungan dari proses ke proses lainnya dalam halaman yang berbeda

Simbol process, yaitu menyatakan suatu tindakan (proses) yang dilakukan oleh komputer

Simbol manual, yaitu menyatakan suatu tindakan (proses) yang tidak dilakukan oleh komputer Simbol decision, yaitu menujukkan suatu kondisi tertentu yang akan menghasilkan dua kemungkinan jawaban : ya / tidak

Simbol predefined process, yaitu menyatakan penyediaan tempat penyimpanan suatu pengolahan untuk memberi harga awal

Simbol terminal, yaitu menyatakan permulaan atau akhir suatu program

Simbol input/output, menyatakan proses input atau output tanpa tergantung jenis peralatannya

Simbol offline-storage, menunjukkan bahwa data dalam simbol ini akan disimpan ke suatu media tertentu

Simbol punched card, menyatakan input berasal dari kartu atau output ditulis ke kartu

Simbol document, mencetak keluaran dalam bentuk dokumen (melalui printer)

Data disimpan secara permanen di dalam disk magnetik; digunakan sebagai master file dan database

\section{Media Flash Card}

Kata media berasal dari bahasa Latin medius yang secara harfiah berarti "tengah", "perantara" atau "pengantar". Mengenai batasan media Gerlach dan Ely sebagaimana dikutip oleh Arsyad mengemukakan bahwa, media apabila dipahami secara garis besar adalah manusia, materi, atau kejadian yang membangun kondisi sehingga siswa mampu memperoleh pengetahuan, keterampilan, atau sikap. Secara lebih khusus, media dalam proses belajar mengajar diartikan sebagai alat-alat grafis, photografis, atau elektronis untuk memproses dan menyusun kembali informasi baik yang bersifat visual maupun verbal.

Flashcard adalah kartu kecil yang berisi gambar, teks, atau tanda simbol yang mengingatkan atau mengarahkan siswa kepada sesuatu yang berhubungan dengan gambar. Flashcard biasanya berukuran $8 \times 12 \mathrm{~cm}$, atau dapat disesuaikan dengan besar kecilnya kelas yang dihadapi.

Menurut Rudi Susilana dan Cepiriyana flashcard merupakan media pembelajaran yang berupa kartu bergambar berukuran 25 X $30 \mathrm{~cm}$. Gambar-gambar pada flashcard merupakan serangkaian pesan yang disajikan dengan adanya keterangan pada setiap gambar.

Flashcard merupakan media grafis yang praktis dan aplikatif. Dari pengertian flashcard di atas yaitu kartu belajar yang efektif mempunyai dua sisi dengan salah satu sisi berisi gambar, teks, atau tanda simbol dan sisi lainnya berupa definisi, keterangan gambar, jawaban, atau uraian yang membantu mengingatkan atau mengarahkan siswa kepada sesuatu yang berhubungan dengan gambar yang ada pada kartu. Maka, dapat disimpulkan bahwa flashcard mempunyai ciri-ciri a) Flashcard berupa kartu bergambar yang efektif. b) Mempunyai dua sisi depan dan belakang. c) Sisi depan berisi gambar atau tanda simbol. d) Sisi belakang berisi definisi, keterangan gambar, jawaban, atau uraian. e) Sederhana dan mudah membuatnya.

Kelebihan media Flashcard menurut Rudi Susilana dan CepiRiyana, flashcard memiliki beberapa kelebihan, antara lain: (a) mudah dibawa-bawa; (b) praktis; (c) gampang diingat; dan (d) menyenangkan.

\section{HASIL DAN PEMBAHASAN}

Kasus penggunaan diagram (Gambar 2) menunjukkan hubungan antara kasus penggunaan dan aktor. Aktor adalah pelajar yang ingin meninjau kosakata. Aktor ini memiliki dua cara untuk meninjau kosakata. Seorang pelajar dapat meninjau kosakata baik menggunakan flashcards atau kuis pilihan ganda. 


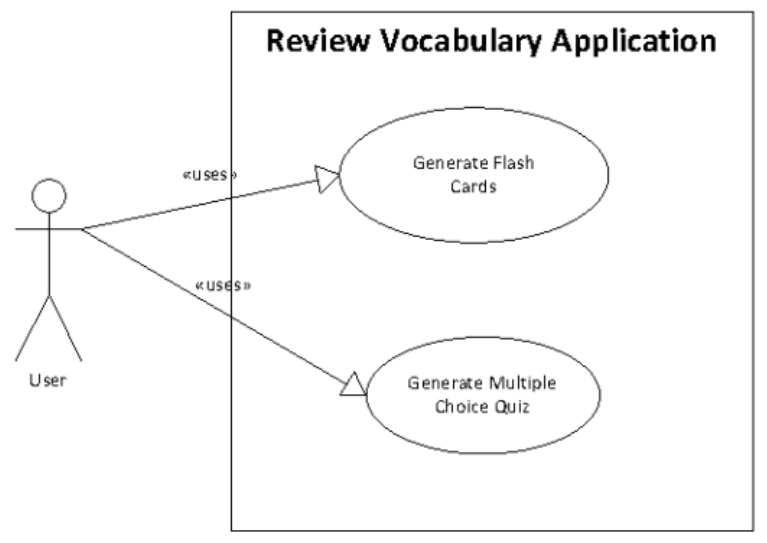

Gbr. 2 Desain umum Vocabulary Application

\section{A. Flowchart Menu Utama}

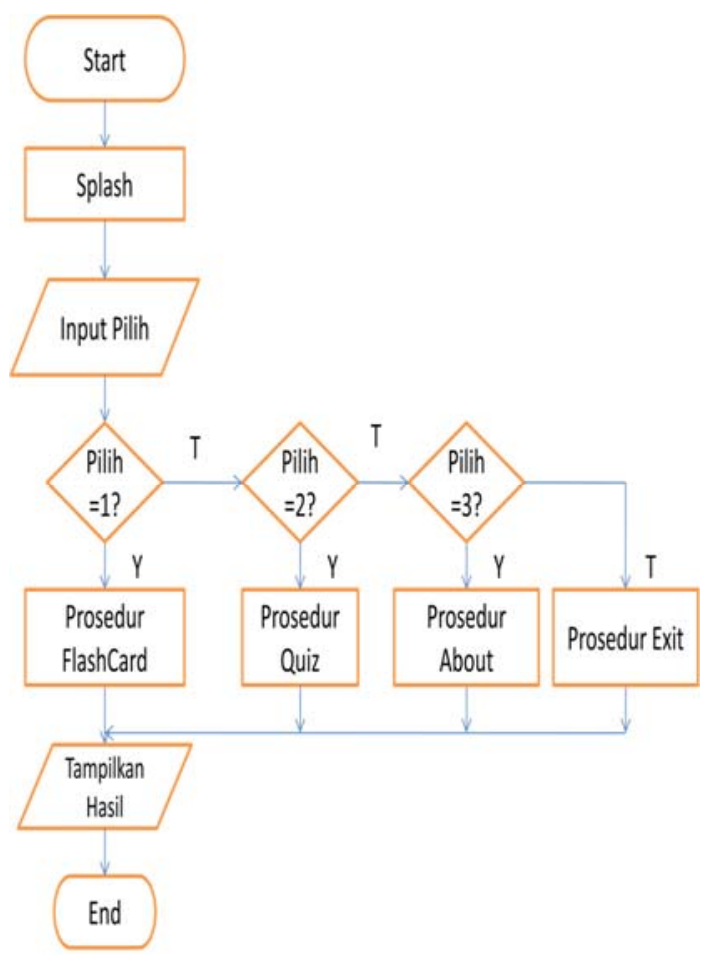

Gbr. 3 Flowchart menu utama

Algortima gambar 2 pada Flowchard menu utama :

1) User memilih menu

- Flashcard

- Quiz

- About

- Exit

2) Bila User memilih menu
- Bila user memilih menu 1,maka ke langkah 3

- Bila user memlih menu 2, maka ke langkah 4

- Bila user memlih menu 3, maka ke langkah 5

- Bila user memlih menu 4, maka ke langkah 6

3) Bila User memilih menu

- User memilih menu 1.

- Akan masuk ke Procedur Flashcard

4) Bila User memilih menu

- User memilih menu 2.

- Akan masuk ke Procedur Quiz

5) Bila User memilih menu

- User memilih menu 3.

- Akan masuk ke Procedur About

6) User memilih menu 4.

- Akan masuk ke Procedur Exit

7) Program selesai.

\section{B. Flowchart Flashcard}

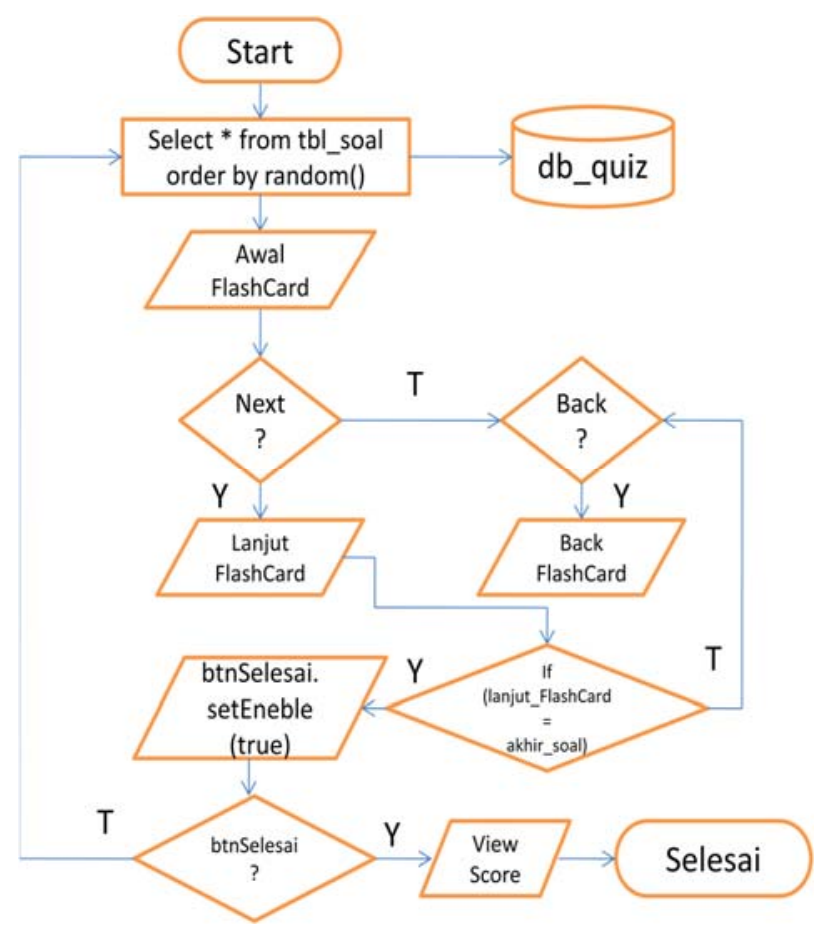

Gbr. 4 Flowchart flashcard

Algortima gambar 3 pada Flowchard flashcard :

1) Program menampilkan FlashCard Carakan Madura dengan memanggil dari database secara random

2) User mengklik Next sampai selesai maka Tombol Selesai Aktif dan klik Back untuk kembali

3) Jika klik tombol Selesai di klik maka akan muncul perintah ingin Keluar atau belajar Lagi

4) Program selesai. 


\section{Flowchart Quiz}

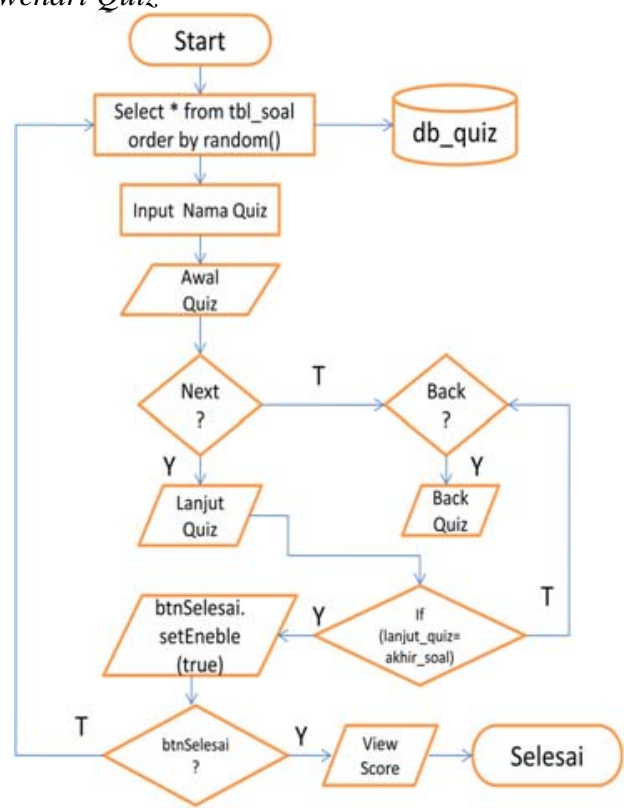

Gbr. 5 Flowchart quiz

Algortima gambar 4 pada Flowchard quiz :

1) Program menampilkan Quiz Carakan Madura dengan memanggil dari database secara random

2) User memilih soal yang ingin di jawab

3) User mengklik Next setelah soal di jawab sampai selesai maka Tombol Selesai akan Aktif dan klik Back untuk kembali

4) Jika klik tombol Selesai di klik maka akan muncul Score Quiz, jawaban Benar dan jawaban Salah serta perintah ingin Keluar atau belajar Lagi

5) Program selesai.

\section{Flowchart Program About}

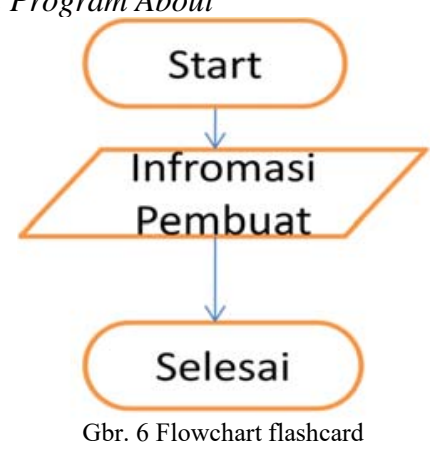

1) Program menampilkan informasi About/pembuat aplikasi

2) Program selesai.

\section{E. Tabel}

Desain Basis Data dapat dibuat dengan berikut :

Nama database db_quiz

Nama tabel tbl soal

\begin{tabular}{|l|l|l|}
\multicolumn{3}{c}{ TABEL II } \\
SOAL \\
\hline Field Name & FieldType & \multicolumn{1}{c|}{ Ket } \\
\hline Id & Integer & Primary Key \\
\hline Soal & Text & \\
\hline Pil_a & Text & \\
\hline Pil_b & Text & \\
\hline Pil_c & Text & \\
\hline Jwban & Integer & \\
\hline Img & Blob & \\
\hline
\end{tabular}

\section{F. Hasil Penelitian}

1) Tampilan Splashing Aplikasi: Tampilan berikut adalah tampilan awal splashing dari aplikasi.

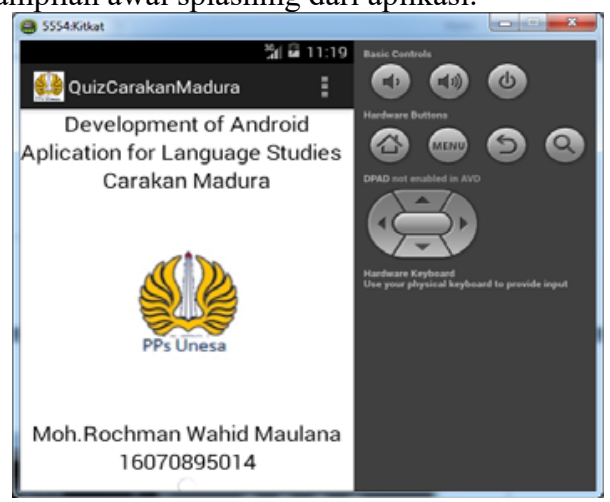

Gbr. 7 Tampilan Splashing Aplikasi

2) Halaman menu utama: Halaman menu utama pada aplikasi.

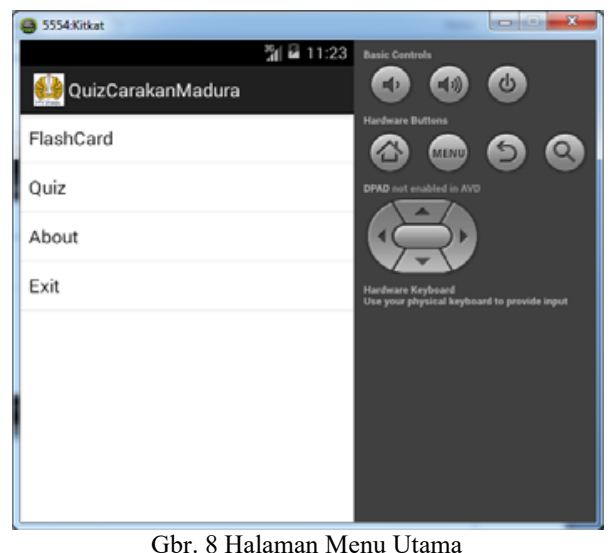

3) Halaman FlashCard: Halaman flashcard merupakan halaman yang berisikan pembelajaran dari carakan madura. 


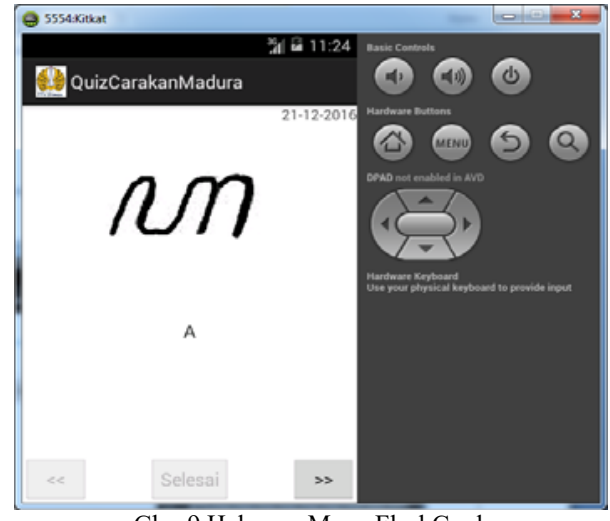

Gbr. 9 Halaman Menu FlashCard

4) Halaman Quiz: Halaman tampilan quiz untuk mengerjakan soal pada soal yang terakhir dengan menekan selesai dan nilai akan menghitung secara otomatis jawaban benar dan salahnya.

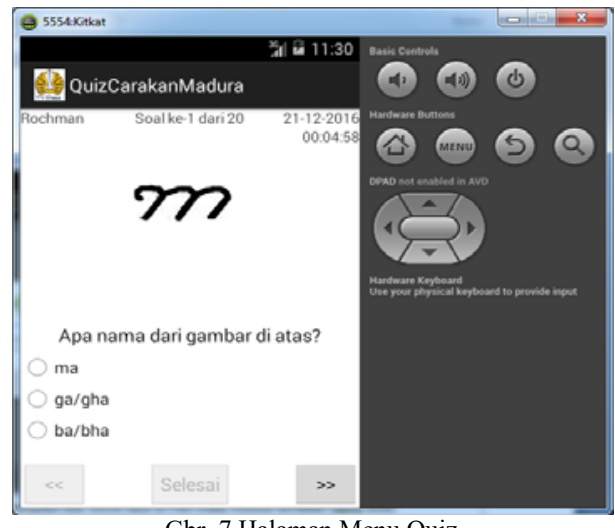

Gbr. 7 Halaman Menu Quiz

5) Halaman About: Halaman biodata dari pembuat serta tujuan dari pembuatan aplikasi ini.

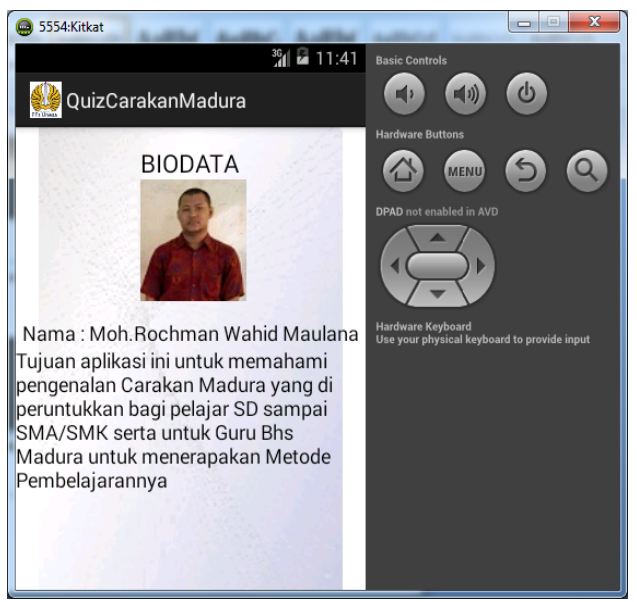

Gbr. 8 Halaman Menu About

\section{KESIMPULAN}

Setelah melakukan seluruh tahapan pembuatan aplikasi bahasa carakan maduara meliputi perancangan, dan implementasi dapat diambil kesimpulan bahwa :

1) Meningkatkan pengetahuan teknologi informasi.

2) Meningkatkan pembelajaran bahasa maduara khususnya Carakan Madura.

3) Mengerjakan soal sistem random.

4) Proses penilaian dengan hasil salah dan benar muncul.

5) Mempermudah guru bahasa madura untuk menerapkan metode pembelajaran.

\section{REFERENSI}

[1] Christoper Dong, Xing Liu. (2013). Development of Android Aplication for Languange Studies. Jurnal ScienceDirect.

[2] Arif Akbarul Huda. (2012). 24 Jam Pintar Pemrograman Andorid. Andi Yogyakarta.

[3] Nazruddin Safaat. (2014). Pemrograman Apliasi Mobile Smartphone dan Tablet PC berbasis Android revisi kedua. Informatika.

[4] Indra Yatini B. (2010). Flowchart, Algoritma dan Pemrograman menggunakan bahasa $\mathrm{C}++$ Builder. Graha Ilmu.

[5] Wahana Komputer (2013) Microsoft Visio Untuk Desain Diagram dan Flowchart. Elex Media Komputindo.

[6] Hendry, ST (2015) Cepat Mahir MySQL dan SQLite. Elex Media Komputindo.

[7] Jubilee Enterprise. (2015). Mengenal Java \& Database dengan Netbeans. Elex Media Komputindo

[8] Azhar Arsyad, Media Pembelajaran, Jakarta: Rajawali Press, 2011, hlm. 3

[9] Azhar Arsyad, Media Pembelajaran, hlm.119-120.

[10]Rudi Susilana dan Cepiriyana, Media Pembelajaran, hlm. 94. 